\title{
PE. CLÁUDIO PERANI: "OBSERVEM E ESCUTEM CUIDADOSAMENTE O QUE AS CRIANÇAS E OS PAIS FALAM"
}

Ao Pe. Claudio um apelo profundo do Espírito o impulsionava continuamente, fazendo-o sair da sua zona de conforto para descer ao encontro dos pobres e excluídos.

Italiano, torcedor do Palmeiras e amante da Fórmula 1. Vivia e falava das realidades deste imenso Brasil com tanta propriedade que mais parecia um de nós brasileiros.

O Pe. Claudio atravessava as margens para se aproximar, respeitosa e cuidadosamente das pessoas, pois não gostava da ideia de vir a magoar alguém. Fazia isso sem julgamentos. O importante era estender uma mão amiga e sempre com expressão amorosa na face, refletindo a intenção misericordiosa de Deus.

Admirável era sua disposição para escutar o próximo. Após um apertar de mãos, deixava de lado o que estava fazendo, pois nada era mais importante naquele momento do que conversar com alguém que procurasse seu auxílio. Todos esses gestos faziam parte de sua bondosa missão. Missionário que rompia barreiras. Um grande colaborador e um observador constante.

Pe. Claudio era um mestre em caminhada. Dedicou toda sua vida tentando realizar as palavras do Evangelho, colocando-se a serviço dos fracos, dos pobres e marginalizados na luta pela terra, pela justiça social e pela participação democrática no exercício da cidadania.

O Projeto Educação e Cidadania (PEC) era uma de suas prioridades. Em 1996 escreveu o primeiro rascunho do PEC e o enviou ao Pe. Geral Kolvenbach SJ, junto com outros dois projetos também novos: Tabatinga e Equipe Itinerante.

O Pe. Claudio acreditava que através das atividades realizadas nos núcleos do PEC poderiam fazer a diferença, construindo uma nova relação social rumo à cidadania plena e participativa. E isso era só possível com a participação ampla de todas as pessoas envolvidas no processo: com as crianças e os pais, com os monitores(as) e os voluntários(as), com os professores(as), etc.

Nas atividades do PEC, sempre orientava: "Primeiro observem e escutem cuidadosamente o que as crianças e os pais falam. Suas esperanças, seus problemas e soluções, seus sonhos. Observem e registrem tudo..." 
O Pe. Claudio nos encorajava sempre. E o mais importante ainda: dizia-nos que não estávamos sozinhos, que as dificuldades não nos podiam desanimar!

Ensinava-nos que no PEC tínhamos um modo próprio de organização; e que essa organização dependia dos desafios encontrados na realidade concreta de cada núcleo.

Para encaminhar os objetivos do PEC, tanto na cidade de Manaus (AM) como no município de Iranduba (AM) tínhamos muito em conta suas orientações: ter como referência as motivações das pessoas, o envolvimento das comunidades, dos pais, das escolas e dos professores, das pessoas voluntárias que ajudavam. E um ponto muito importante foi que todos levaram em conta a realidade concreta de cada local onde se desenvolvia o PEC.

O Projeto se tornou uma rede de núcleos nas comunidades de diversos bairros da periferia de Manaus e de Iranduba. O Pe. Claudio sempre ajudava com uma reflexão sobre o processo da educação que o PEC propunha: "O Projeto é como um 'pronto socorro' para as crianças, onde elas podem aprender e se expressar, complementando a escola convencional..."

Procuramos continuar o sonho do Pe. Claudio e sua luta. Guiados por seus ensinamentos e seus valores, que estavam presentes em todos nós. Buscando a construção de uma sociedade mais justa, onde todos possam ser cidadãos de fato e de direito.

Porém, infelizmente, seu sonho chegou ao fim oito anos depois de sua partida. Como não dependia somente dos meus esforços, não me foi possível realizar o que ele mais me pediu: "Não deixes este Projeto acabar, pois ele faz um bem muito grande para as crianças que não têm oportunidades...".

Agradeço a Deus pela oportunidade de ter conhecido o Pe. Claudio. Agradeço também pelo exemplo de vida, pela amizade, pelo companheirismo no trabalho, por seus ensinamentos constantes..., sempre pautados na coerência de suas atitudes.

Deuzarina de Souza dos Santos*

\footnotetext{
* Educadora Popular, ela foi com o Pe. Claudio Perani SJ fundadora e coordenadora do PEC desde o ano 1997 até 2016, quando lamentavelmente foi fechado o Projeto.
} 